\title{
Comparison of two different laparoscopic hysterectomies: laparoscopic hysterectomy vs. total laparoscopic hysterectomy
}

\section{Farklı iki laparoskopik histerektomi tekniğinin karssılasstınlması: laparoskopik histerektomi ve total laparoskopik histerektomi}

\author{
Mert Göl ${ }^{1}$, Ayşen Kızılyar ${ }^{2}$ \\ ' Department of Obstetrics and Gynecology, Medical School, Çanakkale Onsekiz Mart University, Çanakkale, Turkey \\ ${ }^{2}$ Department of Obstetrics and Gynecology, Gazi Hospital, izmir, Turkey
}

\section{Abstract}

Objective: The aim of this study was to compare the efficacy and safety of laparoscopic hysterectomy (LH) and Total Laparoscopic Hysterectomy (TLH).

Methods: Both types of hysterectomy were performed by retroperitoneal uterine artery sealing using LigaSure ${ }^{\mathrm{TM}}$ by four-puncture. A total of 45 patients were operated on by LH and 22 by TLH. The mean operation time, amount of intraoperative bleeding, drop in hemoglobin concentration, weight of removed uterus, major and minor per-post operative complications, and rate of conversion to the classical abdominal approach in the two groups were compared.

Results: The mean operation time in TLH (110 min.) was significantly longer than in LH (65 min.). This was mainly due to the shorter mean operating time in the vaginal part of LH group (13 min.) compared to laparoscopic dissection of uterosacral ligaments and vaginal suturing (42 min.) in the TLH group. Median blood loss was also significantly higher in the TLH group (278 ml.) compared to the LH group (110 $\mathrm{ml}$.). There were no significant differences in the mean drop of hemoglobin concentration, uterine weight, major and minor complications and conversion to laparotomy between the groups.

Conclusion: LH seems to be a faster and more demanding method than TLH. With its shorter operation time and less bleeding, LH may be preferred to TLH.

(J Turkish-German Gynecol Assoc 2010; 11: 208-11)

Key words: Laparoscopy, hysterectomy, laparoscopic hysterectomy, total laparoscopic hysterectomy

Received: 15 August, 2010

Accepted: 23 October, 2010

\section{Özet}

Amaç: Laparoskopik histerektomi (LH) ile Total laparoskopik histerektomi (TLH) tekniklerinin etkinliği ve güvenilirliğini karşılaştırmak.

Gereç ve Yöntemler: Her iki tip laparoskopik histerektomi dört port ve LigaSure ${ }^{\mathrm{TM}}$ kullanılarak retroperitoneal uterin arter mühürleme yöntemi ile yapıldı. Toplam 45 hasta LH ile ameliyat edilirken, 22 hasta TLH ile ameliyat oldu. Gruplar arasında ortalama operasyon süresi, intraoperative kanama miktarı, hemoglobin de düşüş, uterus ağırlığı, major ve minor ameliyat komplikasyonları, ve laparotomi konversiyon oranları karşılaş̧ırıldı.

Bulgular: TLH uygulanan grupta ortalama operasyon süresi (110 dk.) LH uygulanan gruba göre (65 dk) anlamlı olarak kısa bulundu. Bu farkın nedeni LH grubundaki vajinal etabın (13 dk.), TLH grubundaki uterosakral, kardinal ligamentlerin disseksiyonu ve laparoskopik vajinal sutur uygulama süresine oranla ( $42 \mathrm{dk}$.) anlamlı olarak daha kısa sürmesidir. Ortalama kan kaybı TLH grubunda (278 ml.), LH grubuna gore (110 ml.) anlamlı olarak daha fazla bulunmuştur. Gruplar arasında ortalama hemoglobin düzeyinin düşüşünde, uterus ağırlığında, major ve minör komplikasyonlarda ve laparotomi konversiyon oranlarında anlamlı bir farklılık tespit edilmemiştir.

Sonuç: LH, TLH'ye nazaran daha hızlı ve güvenilir bir cerrahi metod gibi görünmektedir. Özellikle daha kısa ameliyat süresi ve daha az kanama miktarı nedeniyle TLH yerine LH'yi tercih etmeliyiz. (J Turkish-German Gynecol Assoc 2010; 11: 208-11)

Anahtar kelimeler: Laparoskopi, histerektomi, laparoskopik histerektomi, total laparoscopik histerektomi

Geliş Tarihi: 15 Ağustos 2010

Kabul Tarihi: 23 Ekim 2010

\section{Introduction}

After cesarean section hysterectomy is the second most common gynecologic operation performed worldwide (1). Although hysterectomy can be conducted by mini-laparotomy, the vast majority are performed by a laparotomy with a 8-10 $\mathrm{cm}$ incision which enables the patients to tolerate more pain and discomfort compared with the vaginal or laparoscopic routes (2). It is well known that vaginal hysterectomy should be offered to the patient as the first line surgical method for removing her uterus $(3,4)$. However, vaginal hysterectomy is performed in $50 \%$ of patients even in the hands of experienced surgeons because of the limitations due to a large uterus, no previous vaginal delivery, adnexal mass and a history of previous abdominal operation (5). Laparoscopic hysterectomy (LH) is performed much less frequently. There are different types of classifications for LH. However, more recently, three sub-categorisations of LH have been described by Reich et al., (6) which are as follows. (i) Laparoscopic assisted vaginal hysterectomy (LAVH), where

Address for Correspondence / Yazışma Adresi: Mert Göl, M.D., Department of Obstetrics and Gynecology, Medical School, Çanakkale Onsekiz Mart University, Çanakkale, Turkey Phone: +902862180018 Fax: +902862180393 e.mail:mertgol@comu.edu.tr doi:10.5152/jtgga.2010.39 
part of the hysterectomy is performed by laparoscopic surgery and part vaginally, but the laparoscopic component of the operation does not involve division of the uterine vessels.(ii) LH, where the uterine vessels are ligated laparoscopically but part of the operation is performed vaginally. (iii) Total laparoscopic hysterectomy (TLH), where the entire operation (including suturing of the vaginal vault) is performed laparoscopically and there is no vaginal component.

We believe that division of the uterine arteries is the most important part of $\mathrm{LH}$. In a recent study we have shown that, when this step is managed laparoscopically, there is less bleeding and fewer complications (7). According to our experience over 300 laparoscopic hysterectomies in 3 years, we have noticed that there is significant amount of bleeding in the vaginal step of LAVH compared to LH and TLH (unpublished data). Therefore, we suggest that LAVH should be performed by endoscopic surgeons who are inexperienced in laparoscopic hysterectomy and as soon as possible they should progress to LH or TLH. However, it is still not well known whether TLH offers any benefits or disadvantages over LH. This question has not been resolved in recent years and we still do not know which method is best. Accordingly, the aim of the present work was to try to determinel the best method for hysterectomy laparoscopy, TLH or LH.

\section{Materials and Methods}

Intraoperative and postoperative data of both groups were analyzed retrospectively. In time, TLH was performed in all patients instead of LH. Both types of hysterectomy were performed under general anaesthesia with the technique described previously by Köhler et al.,(7). However, in contrast to these authors we used LigaSure ${ }^{\mathrm{TM}}$ V $5 \mathrm{~mm}$ (Valley lab) to seal and cut the uterine vessels instead of using the bipolar cautery (Fig. 1) and infundibulopelvic ligaments (Fig. 2). In the vaginal step of the LH procedure, Ligasure Vmax was used. In TLH uterosacral and cardinal ligaments were also sealed and cut with the Ligasure followed by a circular incision of the vagina using the hook unipolar cautery. The vagina was also sutured laparoscopically in TLH. All operations were performed in the lithotomy position and the drain was only used when indicated. Total operating time (from the maintainence of pneumoperitoneum to vaginal cuff closure), the duration of the vaginal step in LH and also duration of uterosacral and cardinal ligaments dissection within vaginal cuff closure in TLH, estimated blood loss, mean drop in $\mathrm{Hb}$ concentration, uterine weight, rate of intraoperative and post-operative complications, conversion from laparoscopy to the classic abdominal approach, use of blood transfusion and duration of hospital stay were recorded and analyzed. Blood loss was measured by recording the contents of the fluid extraction device. We used the fluid extraction device during the vaginal step, without any surgical pads.

\section{Statistical analysis}

Statistical Analysis was performed using the SPSS ver. 11 (Chicago- IL). Median, medium and percentages of the variables were analyzed. The differences between the two groups were analyzed by Chi - Square test or Mann Whitney U test. A p value $<0.05$ was considered statistically significant.

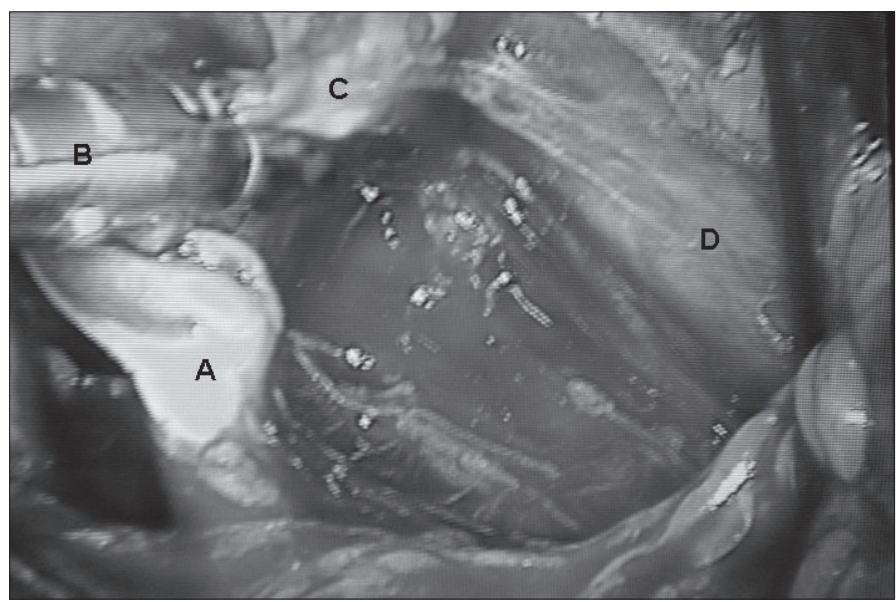

Figure 1. The LigaSure ${ }^{\mathrm{TM}} \mathrm{V} 5 \mathbf{m m}$ (B) is grasping the uterine artery (C) between the internal iliac artery (A) and ureter (D). Note that the suction device is pulling the ureter medially to prevent any damage during sealing

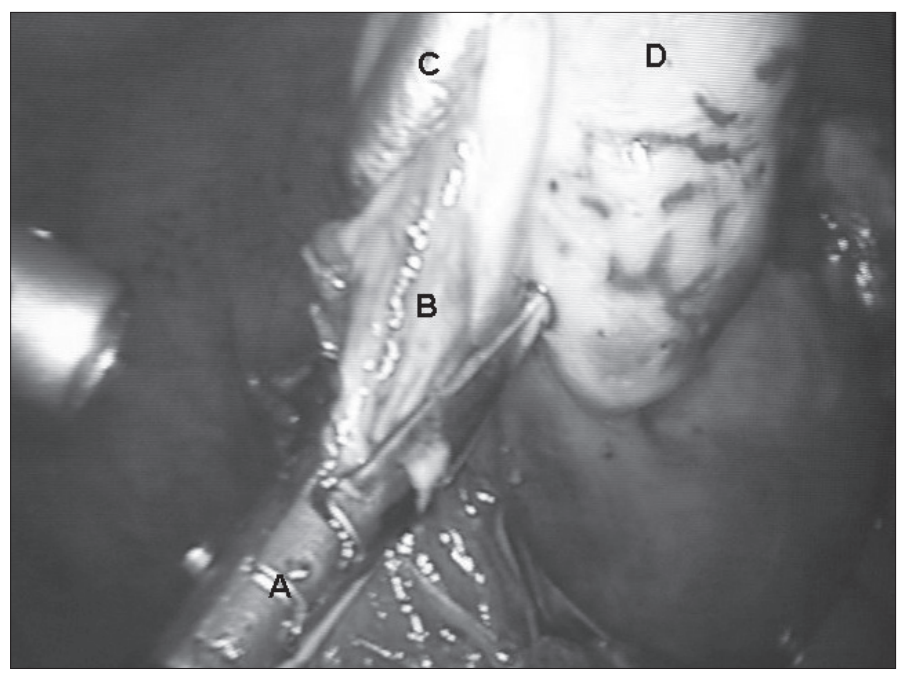

Figure 1. Traction of the infundibulopelvic ligament (B) and ovary (D) upwards by the grasping forceps (C) should be performed for safe, efficient sealing and dissection by the Ligasure (A)

\section{Results}

All operations were performed by the same surgeon (MG). Between February 2006 and March 2007, a total of 116 LH and TLH were performed. Of these, 85 were LH and 31 were TLH. To ensure similar demographic characteristics between the groups, patients with one previous abdominal surgery and with a uterine size smaller than 12 gestational weeks were included. Accordingly, 45 patients in the LH group and 22 in the TLH group were eligible for the inclusion criteria.

Table 1 illustrates the demographic characteristics of patients in both groups. There were no significant differences between the variables. The most common indication for $\mathrm{LH}$ and TLH was an uterine fibroid. As seen in Table 2, there were no significant differences in operation indications between the two groups. Table 3 depicts intraoperative variables in both groups. Total operation time was significantly longer in the TLH group (110 min.) com- 
Table 1. Demographic characteristics of both groups

\begin{tabular}{|l|c|c|c|}
\hline & $\begin{array}{c}\text { TLH } \\
(\mathbf{n = 2 2})\end{array}$ & $\begin{array}{c}\text { LH } \\
(\mathbf{n = 4 5 )}\end{array}$ & $\begin{array}{c}\mathbf{p} \\
\text { value }\end{array}$ \\
\hline Age (years) ${ }^{\mathrm{x}}$ & $46(34-62)$ & $48(37-57)$ & 0.78 \\
\hline $\begin{array}{l}\text { Body Mass Index } \\
\left(\mathrm{kg} / \mathrm{m}^{2}\right)^{\mathrm{x}}\end{array}$ & $25(22-29)$ & $25(22-28)$ & 0.74 \\
\hline Parity $^{\mathrm{x}}$ & $2(0-5)$ & $2(0-4)$ & 0.71 \\
\hline $\begin{array}{l}\text { Previous caesarean } \\
\text { section }\end{array}$ & $6(27.2 \%)$ & $11(24.4 \%)$ & 0.31 \\
\hline $\begin{array}{l}\text { Previous lower abdominal- } \\
\text { pelvic surgery }\end{array}$ & $4(18.1 \%)$ & $9(20 \%)$ & 0.37 \\
\hline${ }^{\mathrm{x}}$ Mann - Whitney U test, ${ }^{8}$ Chi-Square test & & \\
\hline
\end{tabular}

Table 2. Hysterectomy indications

\begin{tabular}{|l|c|c|c|}
\hline & $\begin{array}{c}\text { TLH } \\
(\mathbf{n = 2 2})\end{array}$ & $\begin{array}{c}\text { LH } \\
(\mathbf{n = 4 5 )}\end{array}$ & $\mathbf{p}$ \\
\hline Uterine fibroid & $15(68 \%)$ & $32(71 \%)$ & $<0.05$ \\
\hline Endometrial hyperplasia & $3(13.6 \%)$ & $5(11.1)$ & $<0.05$ \\
\hline Ovarian tumor & $2(9.1 \%)$ & $3(6.6 \%)$ & $<0.05$ \\
\hline Pelvic endometriosis & $1(4.5 \%)$ & - & 0.03 \\
\hline Adenomyosis & $1(4.5 \%)$ & $1(2.2 \%)$ & $<0.05$ \\
\hline $\begin{array}{l}\text { Cervical intraepithelial } \\
\text { neoplasia }\end{array}$ & $2(9.1 \%)$ & $3(6.6)$ & $<0.05$ \\
\hline Postmenopausal bleeding & $1(4.5 \%)$ & - & 0.03 \\
\hline Menorrhagia & - & $1(2.2)$ & 0.03 \\
\hline
\end{tabular}

Table 3. Operative data

\begin{tabular}{|c|c|c|c|}
\hline & $\begin{array}{c}\text { TLH } \\
(n=15)\end{array}$ & $\begin{array}{c}\mathrm{LH} \\
(n=15)\end{array}$ & $\begin{array}{c}\mathbf{p} \\
\text { value }\end{array}$ \\
\hline Total operating time (min)\& & $110(80-170)$ & $65(45-85$ & 0.001 \\
\hline Vaginal step $(\min )^{\&}$ & - & $13(5-22)$ & \\
\hline $\begin{array}{l}\text { Uterosacral and cardinal lig. } \\
\text { dissection and vaginal cuff } \\
\text { closure (min)\& }\end{array}$ & $44(25-72)$ & - & 0.001 \\
\hline Median blood loss $(\mathrm{ml})^{\&}$ & $278(110-420)$ & $110(50-240)$ & 0.042 \\
\hline Median Hb drop (mg/dl)\& & $2.1(0.4-3)$ & $1.6(0.6-2.3)$ & 0.76 \\
\hline $\begin{array}{l}\text { Median uterine weight } \\
\text { (grams) }^{\&}\end{array}$ & $110(60-150)$ & $140(110-220)$ & 0.83 \\
\hline Major Complications ${ }^{*}$ & 1 & 1 & 0.17 \\
\hline Minor Complications* & 3 & 2 & 0.92 \\
\hline Conversion to laparotomy* & 1 & 1 & 0.17 \\
\hline
\end{tabular}

pared to the LH group (65 min) $(\mathrm{p}=0.001)$. This was due to the longer duration in dissecting uterosacral and cardinal ligaments and cuff closure in TLH compared to the vaginal approach to these steps in LH. Intraoperative blood loss was also significantly higher in TLH (278 ml.) compared to LH (110 ml.) $(p=0.004)$.
There were no significant differences in the mean drop of $\mathrm{Hb}$ concentration, uterine weight, rate of intraoperative and postoperative complications and conversion from laparoscopy to the classic abdominal approach between the groups.

Blood transfusion was unnecessary in the two groups. All patients except two with cystotomies were discharged on the first postoperative day. One patient in the TLH group had a cystotomy due to difficulty in dissecting severe adhesions in the vesicovaginal fold becuase of a previous cesarean section. This was repaired laparoscopically and subsequently she developed a vesico-vaginal fistula. The other cystotomy was made in the LH group during the vaginal procedure because of inadequate dissection of the bladder from the vagina. This was repaired vaginally. Only one patient converted to laparotomy in the LH group because of severe bowel adhesions due to rectovaginal endometriosis. Two patients had urinary tract infections and one patient had fever in the TLH group and two patients had fever in the LH group. There were no other minor complications.

\section{Discussion}

During the early years of laparoscopic hysterectomy, LAVH was the main technique performed by endoscopists. However, with time it was noticed that laparoscopic management of uterine arterial pedicles results in less bleeding compared to the vaginal approach in LAVH (8). Furthermore, surgical experience advanced through the years and new techniques in $\mathrm{LH}$ emerged. Experienced surgeons attempted more steps laparoscopically and ultimately they developed the TLH approach. Every laparoscopist has his/her own technique in LH which is most familiar to him/her. Therefore some may advocate performing $\mathrm{LAVH}$ whereas others may prefer to perform $\mathrm{LH}$ or TLH. However, to date, most authors have examined the efficiency of one type of LH and reported their outcomes. In addition, the vast majority were multicenter studies that were biased by different expertise of the surgeons (9-13). A recent multicenter study by Leung WS et al., (14) reported that TLH resulted in longer operating times compared to $\mathrm{LH}$, as was confirmed in our study. Interestingly, these authors reported more intraoperative blood loss in LH than in TLH. However, in our study we showed that the amount of intraoperative bleeding was significantly less in the LH group compared to that of the TLH.group This could be due to use of Ligasure ${ }^{\mathrm{tm}}$ in the present study. Another interesting outcome in the study of Leung WS et al., (14) was that patients in the LH group had higher vaginal cuff hematoma incidence compared to patients in the TLH group. In our study, we did not see a single case of postoperative vaginal cuff hematoma in either group. We again assume that this high incidence of vaginal cuff hematoma could be due to the multicenter nature of their study.

Our technique was first described by Köhler et al., (7) in Germany. However, to date, no study has compared retroperitoenal uterine artery ligation with LigaSure ${ }^{\mathrm{TM}}$ in LH with TLH. In the present study we have shown that LH could be the better technique because of its shorter operation time and less intraoperative bleeding. Patient recovery is rapid, as all were discharged on the subsequent postoperative day. None had any significant complaints and there were no minor long-term postoperative complications, such as urinary tract and wound infections. During laparoscopic hysterectomy, complications should 
be avoided, and preservation of the integrity of the ureter is a major goal when handling the uterine vessel. Although we saw no ureter complications in the present study, we consider that ureteric damage could be much more frequent in TLH than in LH as the surgeon gets much closer to the ureter after the uterine artery step in TLH.

Our study is a case control study, therefore randomized studies are needed to reveal the best method in laparoscopic hysterectomy. Although we obtained statistical significance, there are only a few patients in each group, which could affect the outcomes of some parameters. Accordingly, future randomized studies comparing both methods with anadequate number of patients are needed. However, we suggest that these studies should be performed in a single center and surgeons performing these operations should have similar surgical experience in laparoscopic hysterectomy.

In conclusion, $\mathrm{LH}$ seems to be a faster and more demanding method than TLH. With its shorter operation time and less bleeding, LH may be preferable to performing TLH.

\section{Conflict of interest}

No conflict of interest is declared by authors.

\section{References}

1. Marana R, Busaca M, Zupi E, Garcea N, Paparella P, Catalano GF. Laparascopically assisted vaginal hysterectomy versus total abdominal hysterectomy: A prospective, randomized, multicenter study. Am J Obstet Gynecol. 1999; 180: 270-5.

2. Mahendru R, Malik S, Ss Rana, Gupta S. Hysterectomy through minilaparotomy for benign gynaecological conditions: a valid option. J Turkish-German Gynecol Assoc. 2009; 10: 208-12.

3. Summitt R, Stovall T, Lipscombr S, Lire F. Randomized comparison of laparoscopic assisted vaginal hysterectomy with standard vaginal hysterectomy in an outpatient Setting. Obstet Gynecol. 1992; 80: 895-901.
4. Schwartz R. Complications of laparoscopic hysterectomy Obstet. Gynecol 1993; 81: 1022-5.

5. David-Montefiore E, Rouzier R, Chapron C, Darai E. Hum Reprod. Surgical routes and complications of hysterectomy for benign disorders: a prospective observational study in French university hospitals. 2007; 22: 260-5.

6. Reich H, Roberts L. Laparoscopic hysterectomy in current gynaecological practice. Reviews in Gynaecological Practice 2003; 3: 32-40.

7. Kohler C, Hasenbein K, Klemm P, Tozzi R, Schneider A. Laparoscopicassisted vaginal hysterectomy with lateral transsection of the uterine vessels. Surg Endosc 2003; 17: 485-90.

8. Gol M, Kizilyar A, Eminoglu M. Laparoscopic hysterectomy with retroperitoneal uterine artery sealing using LigaSuretrade mark: Gazi hospital experience. Arch Gynecol Obstet. 2007; 276: 311-4.

9. Song J, Cho SJ, Park CS, Kim SH, Ku PS, Lee MA. Two uterine arterial management methods in laparoscopic hysterectomy. Obstet Gynaecol Res 1998; 24:145-51.

10. Chang WC, Torng PL, Huang SC, Sheu BC, Hsu WC, Chen RJ, et al. Laparoscopic-assisted vaginal hysterectomy with uterine artery ligation through retrograde umbilical ligament tracking.Minim Invasive Gynecol 2005; 12: 336-42.

11. Hoffman CP, Kennedy J, Borschel L, Burchette R, Kidd A. Laparoscopic hysterectomy: the Kaiser Permanente San Diego experience. J Minim Invasive Gynecol. 2005; 12: 16-24.

12. Garry R, Fountain J, Brown J, Manca A, Mason S, Sculpher M, et al. EVALUATE hysterectomy trial: a multicentre randomised trial comparing abdominal, vaginal and laparoscopic methods of hysterectomy. Health Technol Assess. 2004; 8: 1-154.

13. Summitt R, Stovall T, Steege J, Lipscomb G. A multicenter randomised comparison of laparoscopically assisted vaginal hysterectomy and abdominal hysterectomy in abdominal hysterectomy candidates. Obstet Gynecol 1998 92: 321-326.

14. Leung WS, Chan SC, Lo Leslie FS, Pang PC, Pun CT, Yuen MP. Comparison of the different types of laparoscopic total hysterectomy. Journal of Min Inv Gynecol 2007; 12:91-6. 